\title{
原著 論文
}

\section{アクリルレジンとの接着試験による 粘膜調整材の機械的性質}

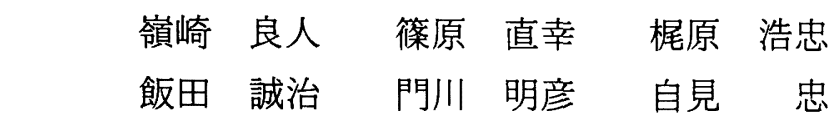

\section{Mechanical Property of Tissue Conditioning Materials Analyzed by Bonding Test to Acrylic Resin}

\author{
Yoshito Minesaki, Naoyuki Shinohara, Hirotada Kajihara, \\ Seiji Iida, Akihiko Kadokawa and Tadashi Jimi
}

\begin{abstract}
Tensile bonding strength to acrylic resin of the tissue conditioning materials were evaluated, at immersed period in distilled water $\left(37^{\circ} \mathrm{C}\right)$ of 1 hour, 6 hours, 1 day, 3 days, 2 weeks and 1 month from the start of mix of tissue conditioning materials. In addition, these materials were evaluated at $360,800,1,600$ and 2,600 times in thermal cycle test $\left(4^{\circ} \mathrm{C}\right.$ to $\left.37^{\circ} \mathrm{C}\right)$. The samples of three acrylic tissue conditioning materials were prepared, and a silicone relining material was used as a control.

Ultimate tensile bonding strength of acrylic tissue conditioning materials increased in accordance with a increase of immersed period for 1 hour to 3 days, and its strengths also increased in thermal for 360 to 1,600. Ultimate tensile bonding strength of silicone material did not change after immersed period of 6 hours and thermal cycles of 800 . The tensile stress of acrylic tissue conditioning materials immersed in distilled water was larger than the values obtained for 3 days to 1 month, compared with those for 1 hour to 1 day. The tensile stress of silicone relining material did not change after immersed period of 6 hours and with a increase of thermal cycle.
\end{abstract}

Key words : tissue conditioning material, tensile bonding strength, stress-strain diagram

\section{I. 緒 言}

粘膜調整材は，一般的には不適切な義歯の粘膜面を

鹿児島大学歯学部歯科補緅学第一講座

First Department of Prosthetic Dentistry Dental School,

Kagoshima University

平成 3 年 10 月 4 日受付
改善し変形した義歯床下粘膜を正常な形態に回復させ ることを目的とする粘膜調整 ${ }^{1,2)}$ ，あるいはダイナミッ ク印象 ${ }^{3)}$ に日常の診療によく用いられる.加えて, 顎 補緅物の実質欠損部の形状决定 ${ }^{4,5)}$ 暫間的なリベー スにも用いられる.

粘膜調整材は徐々に硬化が進むこと ${ }^{6)} ら ，$ 材料の 練和時あるいは練和直後の物理的性質について, 粘弾 性の点から研究7 10) がなされている.しかし, 練和から 
比較的時間の経過した材料の変化については, 報告も 少なく不明な点も多いと思われる ${ }^{9.10)}$. 著者らは練和一 硬化中の粘膜調整材の機械的性質を調べるためにアク リルレジンへの接着強さを測定するとともに, 引張り 試験時の粘膜調整材の応力一歪関係を調べ, 検討した.

\section{II. 材料と方法}

\section{1. 材料}

引張り接着試験には表 1 に示す材料を用いた。用い た材料は,アクリル系の粘膜調整材 3 種 (Soft Liner -ジーシー社製, 以下 SL と略す. Tissue Conditioner -Shōfū 社製, 以下 TC と略す. Coe Comfort-Coe 社 製，以下 CC と略す）と，コントロールとしてのシリ コーン系の軟性裏装材 1 種（Evatouch-Neo 社製，以 下 ET と略す）の計 4 種である。これらの材料を接着 試験に供するまで, 表 1 に示すような条件を設定した。 材料練和後の $37^{\circ} \mathrm{C}$ 蒸留水浸漬は, 1 時間・ 6 時間・1 日・ 3 日・14日・30日浸漬の 6 条件である。熱サイクル試 験には, $4^{\circ} \mathrm{C}$ 蒸留水中 -24 秒, $60^{\circ} \mathrm{C}$ 蒸留水中 -24 秒, 移動一8秒を 1 回とする熱サイクル負荷機を用い, 360 回 $(6.3$ 時間 $) \cdot 800$ 回 $(13.3$ 時間 $) \cdot 1,600$ 回 $(26.7$ 時 間) $\cdot 2,600$ 回 (43.3 時間) の 4 条件の熱サイクルを負 荷した。

接着試験用試料は表 2 に示すような各条件で作製し た。試験に用いたアクリルレジンは直径 $10 \mathrm{~mm}$ の Nikko 社製アクリルレジン棒である. 臨床で粘膜調整 材を応用する場合，使用義歯の粘膜面をカーボランダ ムポイントなどで削合して用いる.アクリルレジンの 表面粗さを表面粗さ測定器サーフコム(東京精密社製) を用いて測定したところ, 10 点平均粗さ（基準長さ 2.5 $\mathrm{mm})$ でカーボランダム切削面が $8 \mu \mathrm{m}$ ，エメリーペー パー180 番での研磨面が $13 \mu \mathrm{m}$ であった。臨床で粘膜 面を一定化するのは困難でカーボランダム切削面の 8 $\mu \mathrm{m}$ より粗くなると思われるので, エメリーペーパー 180 番研磨を使用した.エメリーペーパー180 番にて一 定化したアクリルレジンの接着面は, 蒸留水中にて 10 分間超音波洗浄を行った。粘膜調整材との接着は図 1 に示す金型を用いて行った。試料はアクリル棒間に， 表 2 に示す混液比・練和時間で練和した材料を注入し, 厚さ $2 \mathrm{~mm}$ になるように金型を保持し作製した。その 際，材料中にできるだけ気泡が混入しないように，シ リンジを用いて注入した。

試料作製後, 直ちに表 1 に示す実験条件を負荷した が, その際, 図 2 に示すように厚さ $1 \mathrm{~mm}$ のステンレ ス板にて試料の両側を補強し, 水中浸漬と熱サイクル 試験中の試料の変形を防いだ. 同一条件の試料の数は 5 個である。

\section{2. 測定方法}

実験条件を負荷後, 直ちに引張り接着強さを測定し た。測定には島津製作所製のオートグラフ AG-A 型を 用い,クロスヘッドスピードは $5 \mathrm{~mm} / \mathrm{min}$.にした. 試 験中, 試料がアクリルとの接着面から一部分でもはが れた時点での荷重を最大引張り接着強さとし, 粘膜調 整材の伸びはクロスヘッドスピードとチャート紙から 求めた.

\section{III. 結 果}

\section{1. 最大引張り接着強さ}

実験によって得られたアクリルレジンへの最大引張

表 1 試験材料および実験条件

\begin{tabular}{|c|c|c|c|c|c|c|c|c|c|c|c|c|}
\hline \multirow{3}{*}{ Material } & \multirow{3}{*}{ Manufacturer } & \multirow{3}{*}{ Batch No. } & \multicolumn{10}{|c|}{ Condition } \\
\hline & & & \multicolumn{6}{|c|}{ Period Immersed in Water } & \multicolumn{4}{|c|}{ Thermal Cycle (times) } \\
\hline & & & $1 \mathrm{hr}$. & $6 \mathrm{hrs}$. & 1 day & 3 days & 14 days & 30 days & 360 & 800 & 1,600 & 2,600 \\
\hline Soft Liner & GC & $\begin{array}{l}\mathrm{P}: 041001 \\
\mathrm{~L}: 061001\end{array}$ & 5 & 5 & 5 & 5 & 5 & 5 & 5 & 5 & 5 & 5 \\
\hline $\begin{array}{l}\text { Tissue } \\
\text { Conditioner }\end{array}$ & Shōfū & $\begin{array}{l}\mathrm{P}: 099054 \\
\mathrm{~L}: 099055\end{array}$ & 5 & 5 & 5 & 5 & 5 & 5 & 5 & 5 & 5 & 5 \\
\hline Coe Comfort & Coe & $\left|\begin{array}{l}\mathrm{P}: 030190 \mathrm{~A} \\
\mathrm{~L}: 022790 \mathrm{~A}\end{array}\right|$ & 5 & 5 & 5 & 5 & 5 & 5 & 5 & 5 & 5 & 5 \\
\hline $\begin{array}{c}\text { Evatouch } \\
\text { (Soft) }\end{array}$ & Neo & $\mathrm{FH} 02$ & 5 & 5 & 5 & 5 & 5 & 5 & 5 & 5 & 5 & 5 \\
\hline
\end{tabular}


表 2 各材料の作製過程

\begin{tabular}{|c|c|c|c|}
\hline Material & P/L Ratio & Mixing Time & Setting Time (min.) \\
\hline Soft Liner & 1.22 & $30 \mathrm{sec} .-1 \mathrm{~min}$ & 20 \\
\hline Tissue Conditioner & 1.18 & $30 \mathrm{sec}$. & 20 \\
\hline Coe Comfort & 1.00 & $30 \mathrm{sec}$. & 20 \\
\hline Evatouch (Soft) & 6.50 & $\begin{array}{c}\text { Application of } \\
\text { bonding agent } \\
\downarrow \\
\text { Dry (2 min.) } \\
\downarrow \\
\text { Mixing (1 min.) }\end{array}$ & 20 \\
\hline
\end{tabular}

上方面観
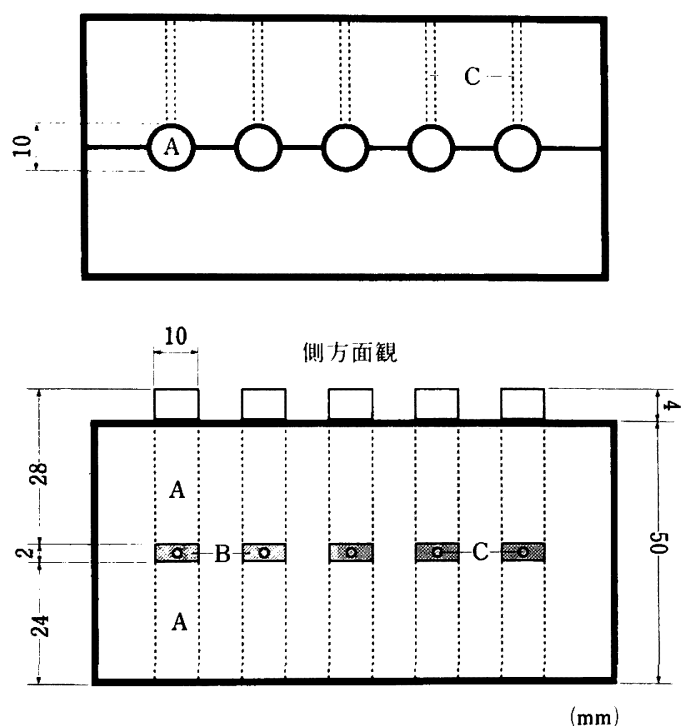
$\mathrm{A}:$ アクリルレジン棒
$\mathrm{B}:$ 粘膜調整材
$\mathrm{C}:$ 遁路

図 1 試料作製に用いた金型

り接着強さを示す. 図 3 は, $37^{\circ} \mathrm{C}$ 蒸留水浸漬後の経時 的な変化を示した片対数のグラフである．横軸は材料 練和からの浸漬時間, 緃軸は最大引張り接着強さを示 している. SL の接着強さは, 練和開始後 1 時間での $1.62 \pm 0.26 \mathrm{~kg} / \mathrm{cm}^{2}$ から 3 日後の $5.18 \pm 0.82 \mathrm{~kg} / \mathrm{cm}^{2}$ まで徐々に増加し，その後はわずかに増加する. TC と $\mathrm{CC}$ の接着強さはそれぞれ 1 時間後での $0.57 \pm 0.04$ $\mathrm{kg} / \mathrm{cm}^{2}, 0.60 \pm 0.09 \mathrm{~kg} / \mathrm{cm}^{2}$ から 3 日後の $2.55 \pm$ $0.24 \mathrm{~kg} / \mathrm{cm}^{2}, 2.38 \pm 0.49 \mathrm{~kg} / \mathrm{cm}^{2}$ までゆるやかに増 加するが, その後大きな変化はみられない. ET は 1 時 間後で $2.23 \pm 0.41 \mathrm{~kg} / \mathrm{cm}^{2}$ であり，その後大きく増加 し, 6 時間後には $10.95 \pm 2.00 \mathrm{~kg} / \mathrm{cm}^{2}$ に達するが, そ

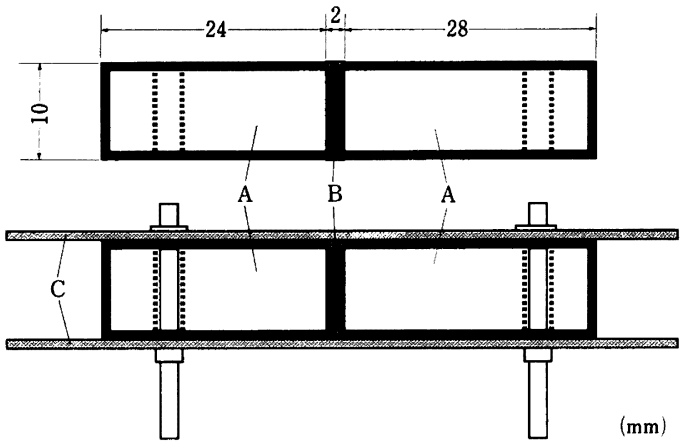
$\mathrm{A}:$ アリリルレジン棒
B : 粘膜調製材
$\mathrm{C}:$ ステンレス板
図 2 試料の模式図

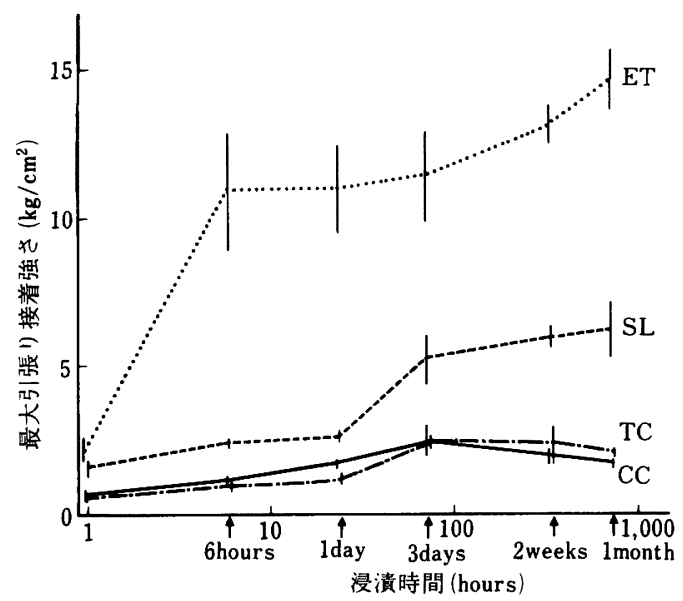

図 3 水中浸清後の最大引張り接着強さの変化 (横軸：対数表示)

の後はゆるやかに增加する。

図 4 は, 熱サイクル負荷後の最大引張り接着強さを 示したものである．横軸は熱サイクルの回数で，（） 内はおのおのの熱サイクルに要した時間を示す. SL, 


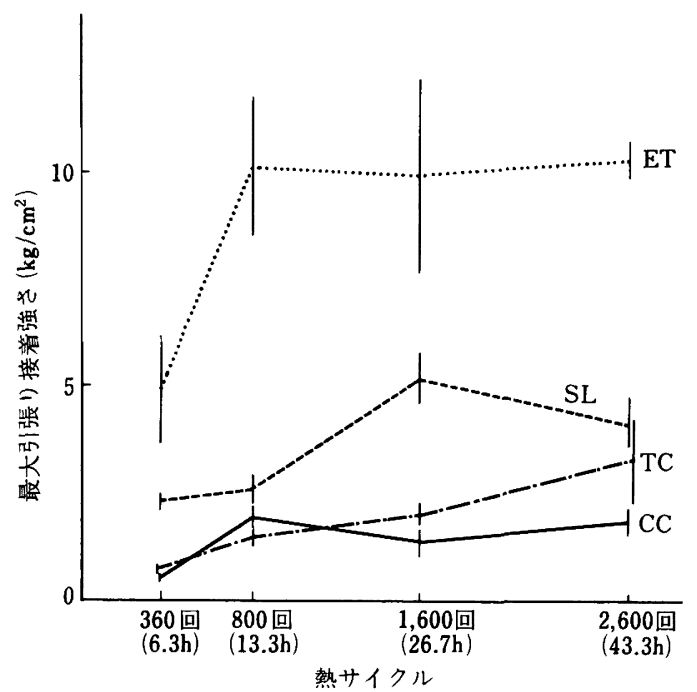

图 4 熱サイクル後の最大引張り接着強さの変化

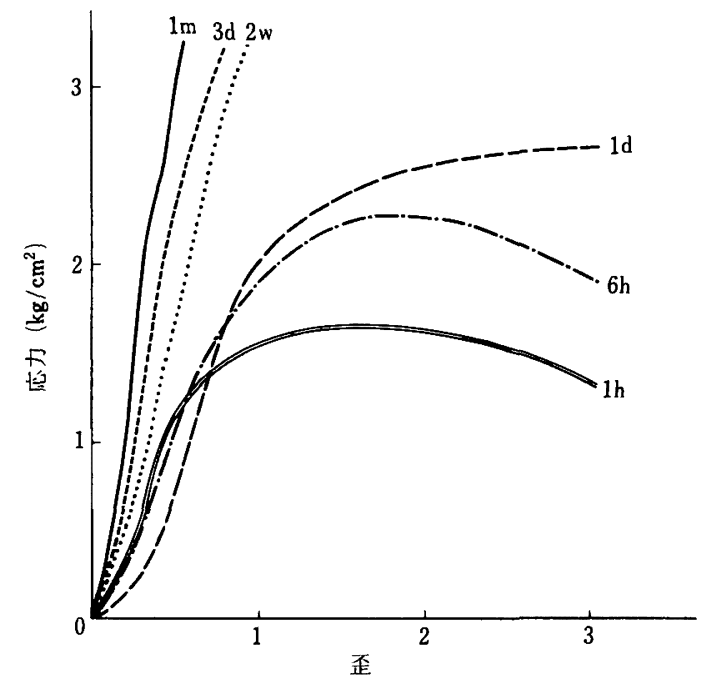

図 5 各水中浸漬時間における SL の応力-歪線図

TC, CC 共熱サイクル回数の増加に伴い, 接着強さは 増加する傾向にある. ET は, 800 回から急激に増加し ている。

\section{2. 引張り試験時の応力と歪の関係}

用いた材料が引張り試験中にどのような挙動を示す かを調べるために, 引張り試験時の応力一歪線図を検 討した.この場合の応力と歪は, 引張り試験時のオー

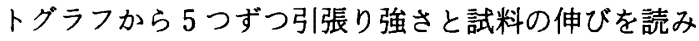
取り，その值から求めた.

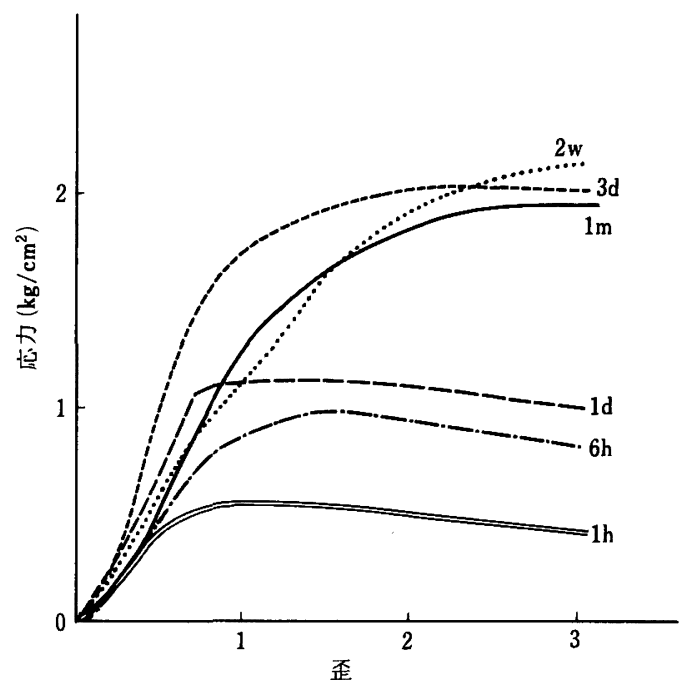

図 6 各水中浸漬時間における TC の応力-歪線図

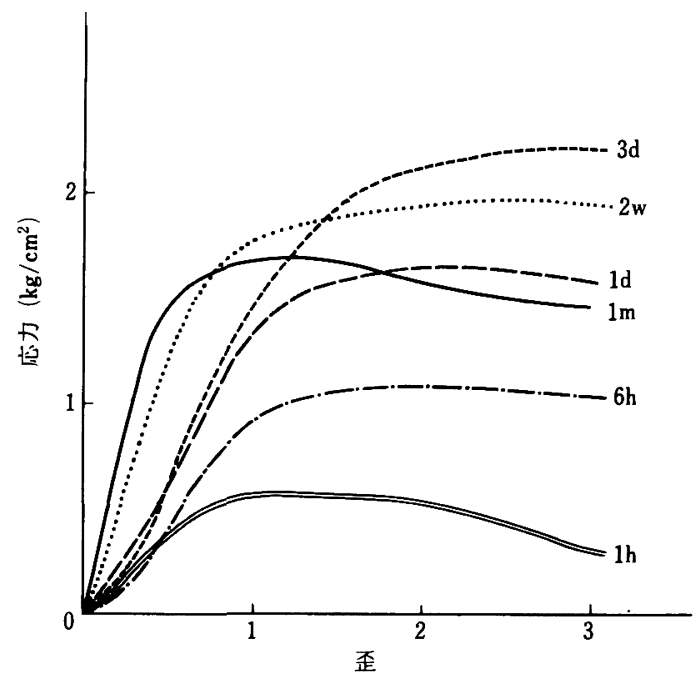

図 7 各水中浸瀆時間における CC の応力-歪線図

図 5 8 は $37^{\circ} \mathrm{C}$ 蒸留水中浸漬後の結果である. 図 5 はSL, 図 6 は TC, 図 7 はCC, 図 8 は ET を示す. SL は練和開始からの時間が経過するに従い, 同じ歪での 応力が大きくなり材料の硬化が進んでいると考えられ る. また, 歪 1 の範囲内の応力一歪関係は, 練和開始 後 3 日まで同じような曲線を示す．しかし，その後は 練和後の時間の経過に伴って, 徐々に硬くなると思わ れる. TC も同様に練和からの時間が経過するに従っ て同じ歪での応力が大きくなり, 材料の硬化が進むこ とが示されるが, 30 日後でも歪が増しても応力は 2 


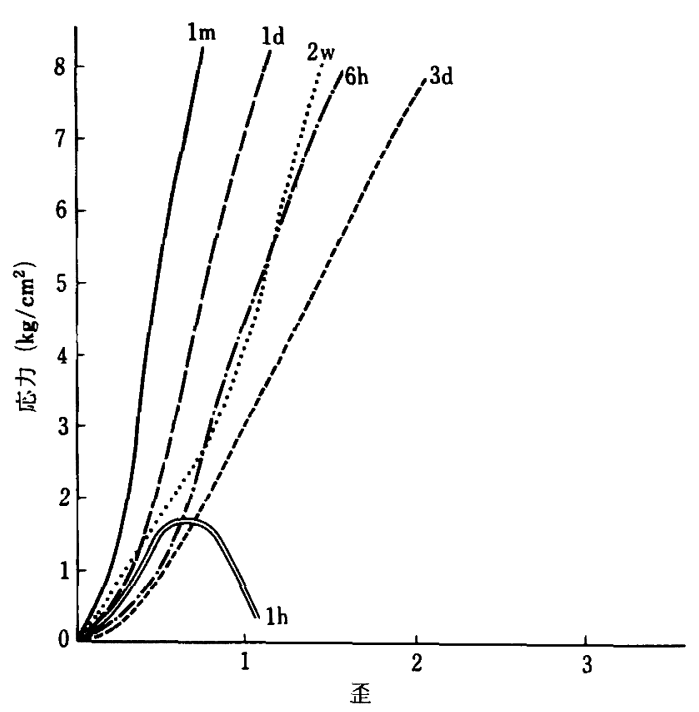

图 8 各水中浸漬時間におけるET の応力-歪線図

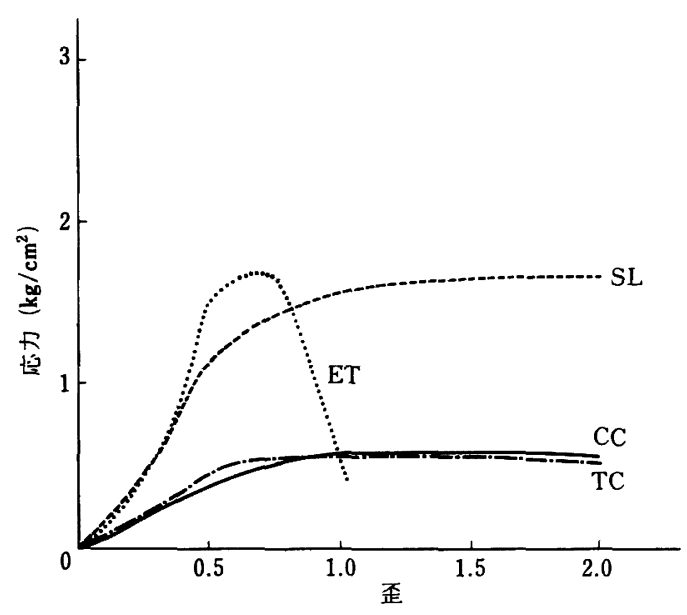

図 9 水中浸婊 1 時間後の各材料の応力-歪線図

$\mathrm{kg} / \mathrm{cm}^{2}$ 程度以下であり, SL に比べ応力が緩和する傾 向がみられる、特に, 練和後 1 日までの間が応力が緩 和する傾向が大きくなっている。

図 7 のCC はほほ TC と同様な挙動を示し, 歪が 1 までの場合練和後 3 日までは，応力が緩和する傾向に 大きな差はみられない.

ET では, 練和後 1 時間までは歪が 0.75 位で応力が $1.8 \mathrm{~kg} / \mathrm{cm}^{2}$ 程度の最大值をとり,材料が硬化途中にあ ることが示唆されるが， 6 時間後からは歪が大きくな るに伴い応力が急激に大きくなり, 材料の硬化が急速 に進んでいると思われる。

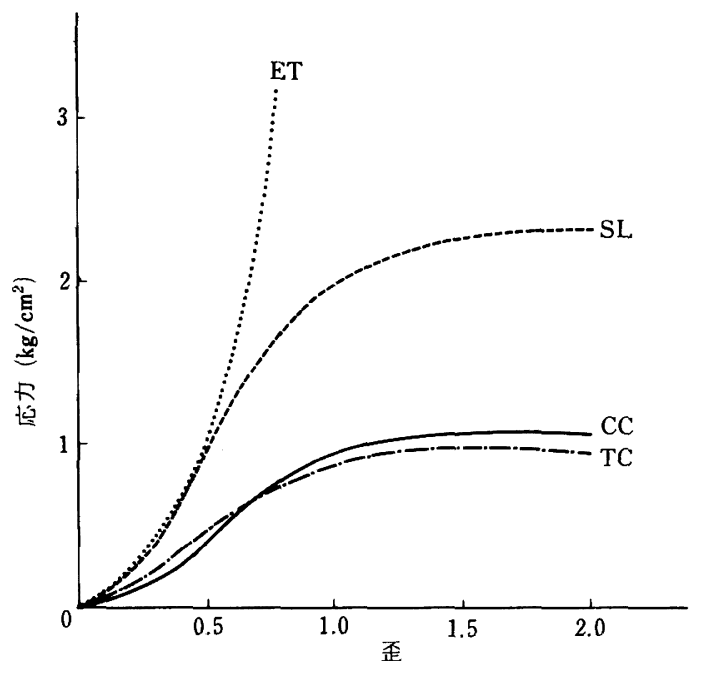

図 10 水中浸漬 6 時間後の各材料の応力-歪線図

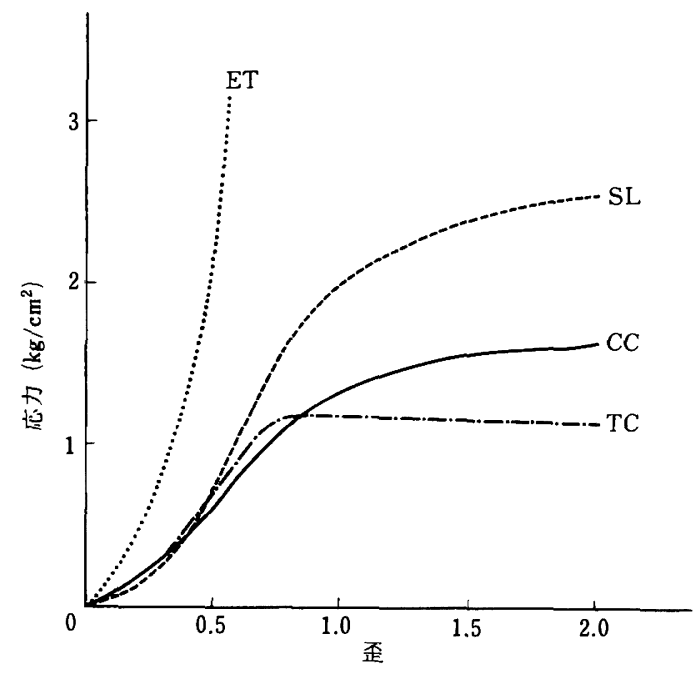

図 11 水中浸漬 1 日後の各材料の応力-歪線図

次に, 応力の緩和する傾向が大きいと思われる $37^{\circ} \mathrm{C}$ 水中浸漬時間 1 時間・ 6 時間・ 1 日・3 日の 4 つの経過 時間ごとの応力一歪線図を図 9〜12 に示す.

図 9 は練和 1 時間後, 図 10 は練和 6 時間後, 図 11 は 1 日後, 図 12 は 3 日後である. 1時間後では TC と $\mathrm{CC}$ がほほ同様な挙動を示し, 歪が 1 になると応力は $0.5 \sim 0.6 \mathrm{~kg} / \mathrm{cm}^{2}$ までゆるやかに增加し, その後は歪 が増加しても応力は増加しない. SL は歪が 1 になる と応力は $1.6 \mathrm{~kg} / \mathrm{cm}^{2}$ 程度に達し, 歪がそれ以上に大 きくなると応力もゆるやかに增加する. ETは歪が 0.75 のとき応力は $1.7 \mathrm{~kg} / \mathrm{cm}^{2}$ に達し, その後はアク 


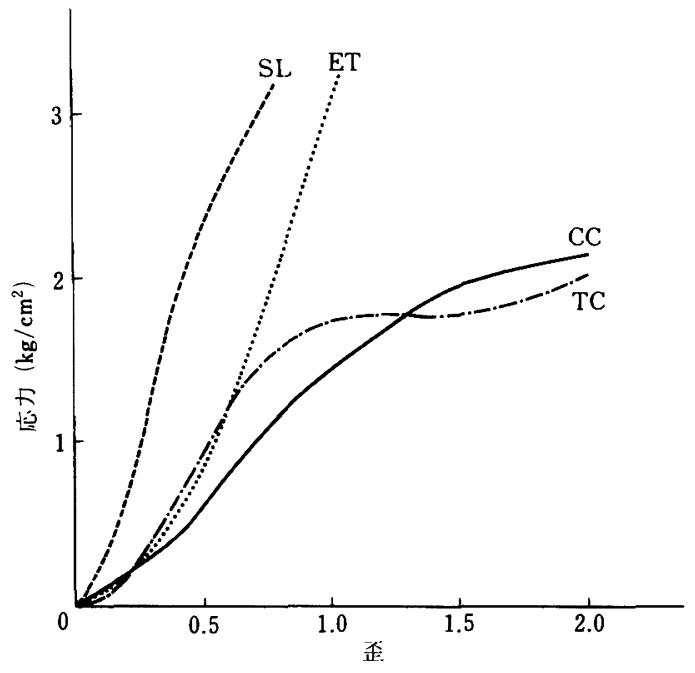

図 12 水中浸漬 3 日後の各材料の応力-歪線図

リルレジンよりはがれる。

図 10 の 6 時間後でも TC と CC はほほ同様な挙動 を示し, 歪が 1 , 応力は $0.85 \sim 0.95 \mathrm{~kg} / \mathrm{cm}^{2}$ までゆる やかに増加し，歪がそれ以上に大きくなっても応力は 増加しない. SL は歪が 2 , 応力が $2.3 \mathrm{~kg} / \mathrm{cm}^{2}$ までゆる やかに増加する. ETは歪が小さい時より応力は大き く増加している。

図 11 の 1 日後では, TC は歪が 0.7 , 応力が $1.2 \mathrm{~kg} /$ $\mathrm{cm}^{2}$ までゆるやかに増加し，それ以上に歪が増加して も応力は増加しない. CC は歪が 1.6 , 応力が $1.6 \mathrm{~kg} /$ $\mathrm{cm}^{2}$ までゆるやかに増加していく. ET は歪が小さい ときより応力は大きく増加する。

図 12 の練和 3 日後では TC は歪が 1 , 応力が 1.75 $\mathrm{kg} / \mathrm{cm}^{2}$ まで増加し, 歪がそれ以上になると応力は微 増していく, CC 江歪が 2 , 応力が $2.15 \mathrm{~kg} / \mathrm{cm}^{2}$ までゆ るやかに増加する. SL は 1 日後までと異なり, 歪が小 さいときより応力は大きく増加する. ET は歪が小さ いときより応力は大きく増加する。

\section{IV. 考察}

\section{1. 最大引張り接着強さ}

今回用いた粘膜調整材 (SL, TC, CC) の水中浸漬 後の最大引張り接着強さは 1 力月後まで徐々に增加し ており, 数日間の粘膜調整には問題のない接着強さで あると考えられる.コントロールとして用いたシリ コーン系の ET は, 他材料に比べ接着強さが大きく,
1 力月後で $14.7 \mathrm{~kg} / \mathrm{cm}^{2}$ まで増加し長時間の裏装材 として応用できると思われる。また，水中浸漬群と熱 サイクル群の引張り接着強さを比較してみると, 熱サ イクル 360 回 (6.3 hrs.) の ET と 1,600 回 (26.7 hrs.) のSL で差が認められたが，その他ではほほ同程度の 值を示しており，2,600回までの熱サイクルによる影 響はほとんどないと考えられる。

なお，本実験では，熱サイクルの条件を最大 2,600 回 に設定した。これは，水中浸漬後の各粘膜調整材の最 大引張り接着強さの変化が 3 日後まで認められ, それ 以降はほとんど変化が認められなかったこと，および 臨床でも粘膜調整材を使用した場合，交換期間は 3 日 程度であることから, 練和後 3 日間における熱サイク ルの影響をみれば十分であると考えたためである。今 回は, 設定した各熱サイクルに要した時間における最 大引張り接着強さと同程度の水中浸漬時間における接 着強さとを単純に比較したが, 今後, 口腔内で実用さ れた場合の条件を考慮して検討を加えていくつもりで ある。

\section{2. 引張り試験時の応力と歪の関係}

図 5〜8 の経時的な材料ごとの応力一歪線図をみる と, 各材料とも練和からの時間の経過に伴って同じ歪 での応力が増加しており材料の硬化が進んでいると考 えられる. シリコーン系の ETは, アクリル系の他の 3 種と違い, 練和 6 時間後から弾性体としての挙動を 示し応力の緩和する傾向はみられない. SL は, CCゃ $\mathrm{TC}$ に比べ練和 1 時間後で硬さに差があり, 時間の経 過とともにますますその差は大きくなり, 練和 3 日後 では ET と同様な応力一歪線図を示した. TC と CC は, ET PSLに比べ応力の緩和する傾向がみられ, 図 9〜12 の各材料の浸漬時間ごとの応力一歪線図をみて もほほ同様な挙動を示している。

粘膜調整材は床下粘膜の過圧部や変形部を正常な形 態に回復させることを目的とするが，その際には義歯 を使用した状態で回復するように作られている。そこ で, 粘膜調整材は応用後のある期間や軟らかさと流れ のある性質を持ち, 義歯床内面をこの材料で一層裏装 すると, 床下粘膜の過圧部や変形部の正常な形態への 復元力に対し，その動きを妨げないないように粘性と 弾性を合せ持つものであることが必要である ${ }^{11,12)}$.

他方, 応力一歪線図から粘膜調整にとって有益な事 項を考える. 応力一歪線図で歪が大きくなっても応力 の増加が大きくない材料は, 歪が大きくなるに伴い応 
力が増加する材料に比べ, 応力の緩和する傾向が大き

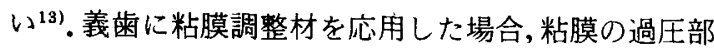
や変形部に当然大きな荷重がかかるが, 荷重がかかり 変形を生じさせようとしてもその粘膜部に対向する義 霜床下の粘膜調整材部の応力が緩和する傾向が大きけ れば大きい程, 粘膜の復元を妨げないということにな る. そういう意味から，粘膜調整には歪の増大に伴い 応力が増加する材料より, 歪が大きくなっても応力が あまり増加しない材料の方が望ましいと考えられる。 以上のことから, 粘膜調整に適した材料は, TCゃ CCのような歪が大きくなっても応力があまり增加し ない材料が望ましいと考えられる，そして，粘膜調整 に適する応用からの期間は, 図 5, 6, 9 12よりこの ような傾向の大きい練和から 3 日位までが望ましいと 考えられる. また,この結果は, 粘弾性についてのこ れまでの研究結果 ${ }^{9,10)}$ と同様の結果を示している. SL で裏装した場合も TCやCC の場合と同様に義歯への 負荷に対してクッション効果を示す。しかし，SLは TC $や \mathrm{CC}$ ほど軟らかくなく応力も緩和しないので, 粘膜調整材として用いるょりも，床下歯肉を咬合圧に 順応させるために, 最終義歯に移行するまでの間, 床 用レジンより軟らかい材料で歯肉をトレーニングする という目的で用いた方が良いと思われる。このことは, 粘弾性からの研究 ${ }^{9,100} に も$ 示されている. ET は粘膜調 整材としては, 不適である。

以上のように，本実験に使用した粘膜調整材はわず か 3 種であるが, その性質を把握して応用する必要が あると思われる。

\section{V. 結 論}

粘膜調整材の機械的性質を調べるために, 粘膜調整 材のアクリルレジンへの引張り接着試験を行い, 接着 強さと引張りへの試験時の応力一歪線図について検討 を行った。その結果, 以下のような結論を得た。

1. アクリルレジンへの接着強さは, ET, SL, TC, CC の順に大きく, 2,600 回までの熱サイクルによる接 着強さへの影響はみられなかった。

2. 練和からの時間が短いほど, 引張り接着試験時 の粘膜調整材の引張り応力が䋸和する傾向が大きかっ
た.

3. 実験を行った材料の中では, TC と CC が応力 の緩和する傾向が大きく, 粘膜調整に有益であるうと 思われた。

本論文の要旨は, 平成 3 年度日本補経歯科学会九州支部学術講 演会 (1991年 9 月 1 日：九州㐘科大学記念講堂)において発表し t.

\section{文献}

1) Chase, W.W. : Tissue conditioning utilizing dynamic adaptive stress, J Prosthet Dent, 11: 804 815, 1961.

2) 佐藤隆志, 津留宏道: 補緅領域における tissue conditioner の応用, 䨑界展望, $51: 293 \sim 302,1978$.

3）鯆見進一，豊田静夫：ダイナミック印象材の所要性質と臨 床応用，歯科ジャーナル，32: 95〜100, 1990

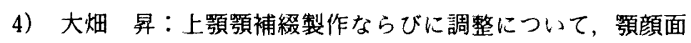
補綴, $13: 57 \sim 70,1990$.

5）大畑 昇：蕷補綴への応用について，歯科ジャーナル， $32: 101 \sim 106,1990$.

6) Phillips, R.W. : Skinner's Science of Dental Materials, Denture base resins: Technical Considerations, 197〜 216, W.B. Saunders Company, Philadelphia, 1973.

7）竹内敏洋：機能印象材のレオロジカルな性質に関する研 究, 九州歯会誌, $37: 282 \sim 303,1983$.

8）鯆見進一：軟性裏装材のレオロジカルな性質と咀噮能力に 及浔す影艟, 九州歯会誌, $38: 864 \sim 879,1984$.

9）平沼謙二, 佐野恭之, 太田 功ほか：粘膜調整材ならびに 軟性裹装材の物理的性質よりみた臨床的評価, DE, 88 ： $27 \sim 34,1989$.

10）平沼謙二, 太田 功, 佐野恭之：ティッシュコンディショ ナーの粘弾性と経時的変化について, 歯科ジャーナル, $32: 5 \sim 11,1990$.

11) McCabe, J.F. (山根正次, 平澤忠): Anderson's Applied Dental Materials（アンダーソン歯科材料学, 118 $\sim 120$, 医蒾薬出版, 東京, 1986), 1985.

12) Craig, R.G. : Restorative Dental Materials, edited by Robert G. Craig, Prosthetic application of polymers, 458 511, The C.V. Mosby Company, St.Louis, 1985.

13) Craig, R.G. : Restorative Dental Materials, edited by Robert G.Craig, Mechanical properties, 60 106, The C. V. Mosby Company, St. Louis, 1985. 